\title{
Cough Reflex Sensitivity and Fractional Exhaled Nitric Oxide in Children With Asthma
}

\author{
Peter KUNC $^{2}$, Jaroslav FABRY ${ }^{2}$, Tomas ZATKO $^{1}$, Marian GRENDAR ${ }^{3}$, Milos TATAR ${ }^{1}$, \\ Renata PECOVA ${ }^{1}$
}

${ }^{1}$ Department of Pathological Physiology, Jessenius Faculty of Medicine in Martin, Comenius University in Bratislava, Martin, Slovak Republic, ${ }^{2}$ Clinic of Paediatric Respiratory Diseases and Tuberculosis, Jessenius Faculty of Medicine in Martin, National Institute of Paediatric Tuberculosis and Respiratory Diseases, Dolny Smokovec, Slovak Republic, ${ }^{3}$ Biomedical Center, Jessenius Faculty of Medicine in Martin, Comenius University in Bratislava, Martin, Slovak Republic

Received March 30, 2020

Accepted October 6, 2020

\begin{abstract}
Summary
Individual studies have suggested the utility of fractional exhaled nitric oxide (FeNO) measurement in detecting cough-variant asthma and eosinophilic bronchitis in patients with chronic cough. The aim of this study was to clarify a correlation of cough reflex sensitivity and fractional exhaled nitric oxide in asthmatic children. 25 children with asthma and 15 controls were submitted to cough reflex sensitivity measurement - capsaicin aerosol in doubling concentrations (from 0.61 to $1250 \mu \mathrm{mol} / \mathrm{l}$ ) was inhaled by a single breath method. Concentrations of capsaicin causing two (C2) and five coughs (C5) were reported. Fractional exhaled nitric oxide (FeNO) measurement was included. Asthmatic children (11 boys and 14 girls, mean age $9 \pm 1$ years) and control group (unconfirmed diagnosis of asthma) ( 6 boys and 9 girls, mean age $8 \pm 1$ years) were included into the study. FeNO vs. C2 in asthma (Spearman's rank correlation: $-0.146, p=0.49$ ); FENO vs. C5 in asthma (Spearman's rank correlation: $-0.777, p=0.71$ ). We found that there is no correlation between cough reflex sensitivity and fractional exhaled nitric oxide either in children with asthma or in the control group.
\end{abstract}

\section{Key words \\ Cough • Cough reflex sensitivity $\bullet$ FeNO $\bullet$ Children • Asthma}

\section{Corresponding author}

R. Péčová, Department of Pathological Physiology, Jessenius Faculty of Medicine in Martin, Comenius University in Bratislava, Malá Hora 4C, 03601 Martin, Slovak Republic. E-mail: renata.pecova@uniba.sk

\section{Introduction}

Cough is a vital protective reflex preventing aspiration and enhancing airway clearance. However, pathologically excessive and protracted cough is a common and disabling complaint (Morice et al. 2020). The commonly used definition of chronic cough in children is 4 weeks, although cough in children lasting 3-8 weeks has been termed prolonged acute cough (Chang and Glomb 2006, Shields et al. 2008). Irrespective of the exact duration, chronic cough in children is different from that in adults due to differences in the airway morphology, a higher degree of vulnerability to noxious insults, reduced control of the cough reflex and differences in maturation of the neurological and immunological system in the different pediatric age groups (Chang 2010). Chronic cough in children is best seen as a symptom of an underlying disease. Cough may be caused by excessive stimulation of a normal cough reflex such as occurs following inhalation of a foreign body or noxious vapors. However, most patients presenting with a chronic cough have features of cough reflex hypersensitivity, responding to exposure to low levels of thermal, chemical or mechanical stimulation (Morice et al. 2014). The cough hypersensitivity syndrome has been adopted as an overarching diagnosis with the different phenotypes dependent on the type and location of the inflammation seen. Both central and peripheral mechanisms have been postulated for cough reflex hypersensitivity (Mazzone et 
al. 2018).

Asthma is a clinical diagnosis. There is no agreed single diagnostic test to diagnose or exclude asthma, and because of its heterogeneous presentation opinions differ on how to describe the syndrome in patients with chronic cough. Eosinophilic inflammation may be a useful biomarker of asthmatic cough and may have utility in directing therapeutics. All adults and children with chronic cough may be assessed for eosinophilic inflammation. Sputum eosinophilia is perhaps the most accurate indicator, but is not routinely available, is time-consuming and requires expert interpretation. Exhaled nitric oxide can be used as a surrogate marker of eosinophilic airway inflammation and steroid responsiveness in classic asthma, but its role in asthma and chronic cough is questioned (Morice et al. 2020).

The first report on the presence of gaseous nitric oxide (NO) in exhaled human breath dates from 1993 (Borland et al. 1993). Four years later, it was found in higher than normal concentrations in children with asthma (Nelson et al. 1997), and higher still during asthma exacerbations, while it dropped rapidly following oral steroid therapy (Baraldi et al. 1997). As a result, the early 2000s saw a considerable number of publications exploring the relationship between fractional concentrations of exhaled nitric oxide ( $\mathrm{FeNO}$ ) and asthma. Nitric oxide (NO) may play an essential role in regulating airway function and in the pathophysiology of inflammatory airway diseases (Barnes 1995). NO is generated by NO synthase (NOS) from L-arginine in vivo (Kobzik et al. 1993). Nitric oxide in the respiratory system is produced mainly by two enzymes: constitutive nitric oxide synthase, which constantly generates low concentrations of NO, and inducible NOS (iNOS), the expression of which is prompted by various inflammatory cytokines (Turner 2015, Kim et al. 2016, Ferraro et al. 2018). High concentrations of NO may have not only beneficial functions (e.g. antibacterial, antiparasitic and antiviral), but also detrimental results, such as endotoxin shock (Kilbourn et al. 1990), apoptosis (Lipton et al. 1993), and pro-inflammatory effects (Barnes 1996, Hesse et al. 2004).

Exhaled nitric oxide (ENO) is at significantly elevated levels in bronchial asthma patients compared to healthy subjects (Kharitonov et al. 1994). Immunostaining of biopsied bronchial mucosa has shown that iNOS is generally present in much more amounts in the bronchial epithelium of bronchial asthma patients than normal subjects (Hamid et al. 1993). The augmentation of ENO results from increased iNOS expression in the airway of bronchial asthma patients. ENO measurements are recognized as a good surrogate marker for eosinophilic airway inflammation (Taylor et al. 2006). ENO levels in cough variant asthma patients were similar to those in bronchial asthma patients (De Diego et al. 2005).

Increased cough reflex sensitivity to inhaled capsaicin has been reported in chronic cough associated with eosinophilic airway inflammation, such as nonasthmatic eosinophilic bronchitis (Brightling et al. 2000), and atopic cough (Fujimura et al. 2000). It is still controversial in bronchial asthma (Fujimura et al. 1992, Doherty et al. 2000). No study has investigated the relationship between cough reflex sensitivity and FeNO in asthmatic children. NO is involved in both the normal cough reflex circuit and increased cough reflex sensitivity induced by allergic reaction (Hori et al. 2011). NO produced by iNOS might be a promoter in cough reflex sensitivity in asthmatic children which were of changed cough reflex sensitivity associated with allergic eosinophilic airway inflammation.

In this study, we hypothesized that NO produced by iNOS might be a promoter in cough reflex sensitivity, and therefore we performed a correlation between fractional nitric oxide ( $\mathrm{FeNO}$ ) and cough reflex sensitivity in healthy and asthmatic children.

\section{Methods}

\section{Selection criteria and subjects}

Children were referred to National Institute of Paediatric Tuberculosis and Respiratory Diseases, Dolny Smokovec, Slovak Republic by their pediatric pulmonologist. The inclusion criteria to enter the study were: 1) age from 8 to 12 years, 2) positive anamnesis of chronic cough, cough lasting longer than 4 weeks (Chang et al. 2001, Chang et al. 2017), 3) status without signs of acute airway inflammation and signs of respiratory disorders with exclusion of obstructive ventilatory defect verified by auscultation by pediatrician, spirometry examination by Geratherm Spirostik (Geratherm Respiratory GmbH, Germany) - baseline FEV1 was larger than $80 \%$,4) good cooperation during the spirometry and cough reflex sensitivity (CRS) examination with relevant outcomes (hyporeactors were excluded), 5) diagnosed bronchial asthma based on current GINA guidelines (Bateman et al. 2018, Hogan and Bernstein 2019), 6) bronchodilatator treatment was discontinued $72 \mathrm{~h}$ before being examined. All children who met the given criteria 
underwent CRS and FeNO measurements. Asthmatic children' (11 boys and 14 girls, mean age $9 \pm 1$ years) were included into the study. The control group ( 6 boys and 9 girls, mean age $8 \pm 1$ years) consisted of children with the presumed unconfirmed diagnosis of bronchial asthma.

The study was approved by the institutional Ethics Committee and was performed according to the Declaration of Helsinki. Each parent of the observed child was properly informed about the study, about the possibilities of cough treatment and was asked to sign an informed consent.

Spirometry, cough reflex sensitivity testing and FeNO measurement

All subjects underwent initial screening of their basic lung functions measured by spirometry before and after capsaicin challenge (Geratherm Spirostik; Geratherm Respiratory GmbH, Germany), to rule out airway obstruction.

CRS was assessed using capsaicin cough challenge, performed in agreement with the ERS guidelines (Morice et al. 2007) with modification for pediatric use (Varechova et al. 2008) (we used a compressed air-driven nebulizer (model 646; DeVilbiss Health Care, Inc., Somerset, PA, USA) controlled by a dosimeter (KoKo DigiDoser-Spirometer; nSpire health Inc., Louisville, CO, USA) with an inspiratory flow regulator valve added (RIFR; nSpire Health Inc., Louisville, CO, USA) to assign identical inspiratory flow rate during capsaicin inhalations in all subjects. Each subject inhaled saline randomly interposed among 12 inhalations of incremental capsaicin aerosol concentrations (0.61-1250 $\mu \mathrm{mol} / \mathrm{l})$. Each administration of saline and capsaicin aerosol was performed at $1 \mathrm{~min}$ intervals with the inhalation time set at $400 \mathrm{msec}$. The number of coughs within $30 \mathrm{~s}$ after aerosol administration was counted. The end-point of cough challenge was the inhalation of capsaicin concentration that provoked at least 5 coughs (C5) or when the maximum concentration of capsaicin $(1250 \mu \mathrm{mol} / \mathrm{l})$ was achieved. The con-centration of capsaicin causing at least two coughs was assigned as $\mathrm{C} 2$ and concentration of capsaicin causing at least 5 coughs was assigned as C5. For children that did no cough at any concentration of capsaicin, CRS value was assigned $1250 \mu \mathrm{mol} / \mathrm{l}$.

The CRS measurement was realized as a singledose capsaicin test. Gradually, with the increasing concentrations of capsaicin we determined sensitivity threshold of the airway nerve endings responsible for coughing.

FeNO measurement was realized by Niox Vero ${ }^{\circledR}$ (Aerocrine AB, Solna, Sweden). The examination was carried out on the basis of the ATS/ERS methodological recommendations (American Thoracic Society and European Respiratory Society, 2005).

Obtained parameters of CRS and FeNO were mutually statistically compared and relation between CRS and FeNO was statistically evaluated. The results were evaluated and interpreted for a group of patients and the control group.

\section{Statistical analysis}

Results with p-value below 0.05 were considered statistically significant. Software used: R Core Team (2015), R: A language and environment for statistical computing ( $\mathrm{R}$ Foundation for Statistical Computing, Vienna, Austria, URL - https://www.R-project.org/, $\mathrm{R}$ version 3.2.3, 2015-12-10) (Maechler et al. 2016).

\section{Results}

Asthmatic children (11 boys and 14 girls, mean age $9 \pm 1$ years) and the control group ( 6 boys and 9 girls, mean age $8 \pm 1$ years) were included into the study.

There was no correlation between FeNO and cough reflex sensitivity (C2) either in asthmatic children (Spearman's rank correlation: $-0.146, p=0.49$ ) or in the control group (Spearman's rank correlation: 0.013; $\mathrm{p}=0.96$ ) (Fig. 1). We didn't find the correlation between cough reflex sensitivity (C5) and FENO either in asthmatic children (Spearman's rank correlation: $-0.777, \mathrm{p}=0.71$ ) or in the control group (Spearman's rank correlation: 0.358; $\mathrm{p}=0.18$ ) (Fig. 2).

\section{Discussion}

The aim of this study was to clarify the correlation of cough reflex sensitivity and fractional exhaled nitric oxide in asthmatic children. We found that there is no correlation between cough reflex sensitivity and fractional exhaled nitric oxide either in the children with asthma or in the control group.

Chronic cough is a common entity in respiratory medicine. It is a complex disorder, the management of which has recently been defined in the guidelines of the European Respiratory Society (Morice et al. 2020). Several intrinsic and extrinsic factors can contribute to hypersensitivity in the cough reflex, and $\mathrm{T}_{\mathrm{H}} 2$ cell-mediated 
airway inflammation is one of the major triggers of this condition (Morice et al. 2014). The diagnostic approaches for cough-variant asthma (CVA) and eosinophilic bronchitis (EB), two common conditions with $\mathrm{T}_{\mathrm{H}} 2$ inflammation, have been an integral part of the clinical guidelines for chronic cough (Morice et al. 2020). Since the discovery of the biological roles of endogenous nitric oxide (NO) and the standardization of simple analyzers of exhaled NO in the 1990s (Barnes and Belvisi
1993), fractional exhaled nitric oxide (FeNO) has been suggested as a potential biomarker for $\mathrm{T}_{\mathrm{H}} 2$ inflammation (Alving and Malinovschi 2010). The great advantage of measuring FeNO values is that it only requires a simple, rapid, and noninvasive test, potentially enabling the test to be widely used in clinical practice. FeNO levels were significantly higher in patients with asthmatic cough than in those with nonasthmatic cough (Asano et al. 2017).

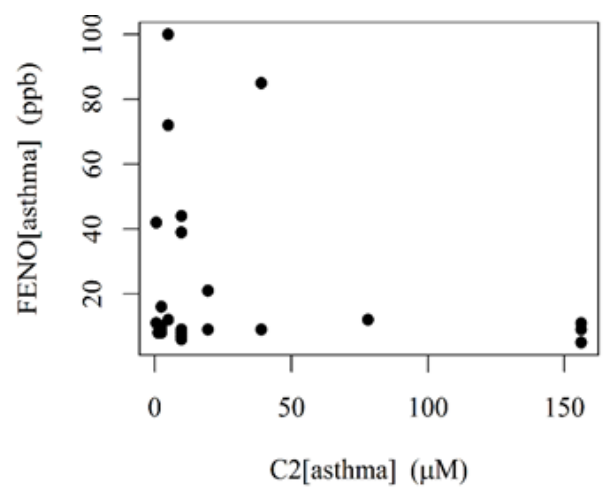

Fig. 1. Cough reflex sensitivity (C2) vs. FeNO in asthmatic children and control group. Control group - Spearman's rank correlation: $0.013 ; p=0.96$. Asthma group - Spearman's rank correlation: $-0.146 ; p=0.49$.
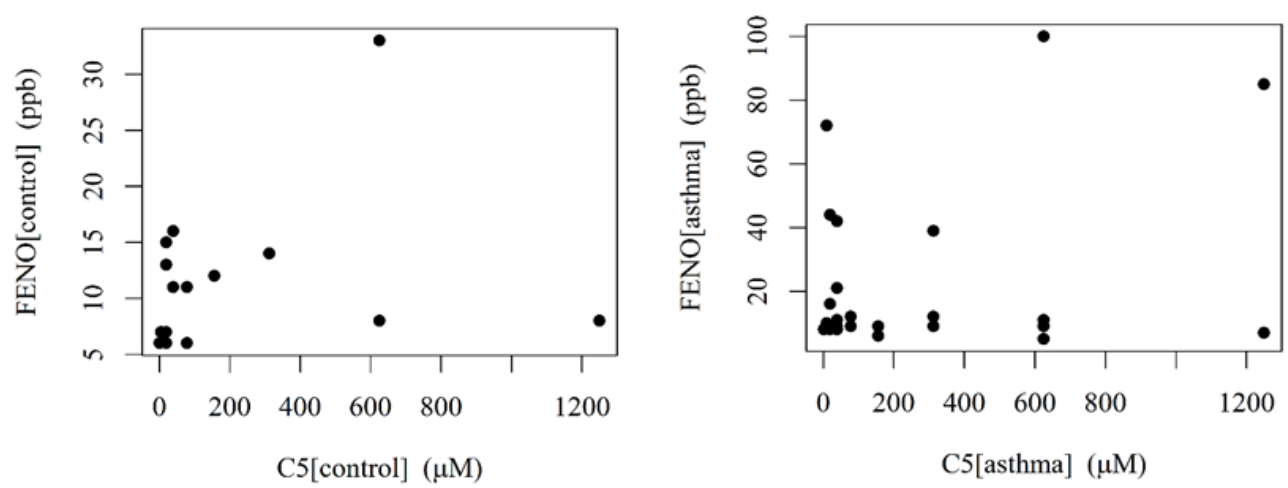

Fig. 2. Cough reflex sensitivity (C5) vs. FeNO in asthmatic children and control group. Control group - Spearman's rank correlation: $0.358 ; p=0.18$. Asthma group - Spearman's rank correlation: $-0.777 ; p=0.71$.

The field of biomarker research in asthma is under continuous expansion with large-scale omics technologies facilitating the discovery of novel 'hits'. However, to date the only biomarkers in clinical use are FeNO and blood eosinophils (B-Eos) where elevated levels support ongoing type 2 inflammation and may identify candidates for novel biological treatments. FeNO can support an asthma diagnosis and has several potential roles in therapy with regard to assessing compliance and identifying candidates in need of increased inhaled corticosteroid (ICS) therapy, but also to aid down-titration of ICS, although further confirmation is required for the latter. B-Eos counts may play a role in prognosis being associated with increased exacerbations and reduced lung function. Additional clinical benefit may also be provided by the combined use of B-Eos and FeNO (Mogensen et al. 2020).

Non-selective NOS inhibitor L-NAME totally suppressed cough reflex sensitivity to inhaled capsaicin and reduced ENO in both non-sensitized and OVA-sensitized guinea pigs. On the other hand, although ONO1714 showed a partial suppression of cough reflex sensitivity associated with further ENO suppression in OVA-sensitized guinea pigs, it had no antitussive effect despite 
ENO suppression in non-sensitized guinea pigs. ONO1714 did not influence BAL cell components $48 \mathrm{~h}$ after OVA challenge in sensitized animals. NO is involved in both the normal cough reflex circuit and increased cough reflex sensitivity induced by allergic reaction (Hori et al. 2011). However, the pathway of involvement is too complex to be explained by these results.

Limitation in this study that should be noted include the following: The unequal number of boys and girls and the sample size used in the study was rather small. Having a small sample size made the statistical results not as objective as they would be if a larger sample size had been used. In the future studies, these limitations should to be addressed.

\section{Conclusions}

We found that there is no correlation between cough reflex sensitivity and fractional exhaled nitric oxide either in children with asthma or in the control group. The precise mechanism of action need to be investigated in future studies. Possibly other biomarkers of asthma need to be added.

\section{Conflict of Interest}

There is no conflict of interest.

\section{Acknowledgements}

This work was supported by the project of Ministry of Health of the Slovak Republic - 2018/12-UKMT-8.

\section{References}

ALVING K, MALINOVSCHI A: Basic aspects of exhaled nitric oxide. Eur Respir Mon 49: 1-31, 2010. https://doi.org/10.1183/1025448x.00028509

AMERICAN THORACIC SOCIETY; EUROPEAN RESPIRATORY SOCIETY: ATS/ERS recommendations for standardized procedures for the online and offline measurement of exhaled lower respiratory nitric oxide and nasal nitric oxide, 2005: Am J Respir Crit Care Med 171: 912-930, 2005. https://doi.org/10.1164/rccm.200406710ST

ASANO T, TAKEMURA M, FUKUMITSU K, TAKEDA N, ICHIKAWA H, HIJIKATA H, KANEMITSU Y, UEMURA T, TAKAKUWA O, OHKUBO H, MAENO K, ITO Y, OGURI T, NAKAMURA A, NIIMI A: Diagnostic utility of fractional exhaled nitric oxide in prolonged and chronic cough according to atopic status. Allergol Int 66: 344-350, 2017. https://doi.org/10.1016/j.alit.2016.08.015

BARALDI E, AZZOLIN NM, ZANCONATO S, DARIO C, ZACCHELLO F: Corticosteroids decrease exhaled nitric oxide in children with acute asthma. J Pediatr 131: 381-385, 1997. https://doi.org/10.1016/S0022-3476(97)80062-5

BARNES PJ: Nitric oxide and airway disease. Ann Med 27: 389-393, 1995. https://doi.org/10.3109/07853899509002592

BARNES PJ: NO or no NO in asthma? Thorax 51: 218-220, 1996. https://doi.org/10.1136/thx.51.2.218

BARNES PJ, BELVISI MG: Nitric oxide and lung disease. Thorax 48: 1034-1048, 1993. https://doi.org/10.1136/thx.48.10.1034

BATEMAN ED, HURD SS, BARNES PJ, BOUSQUET J, DRAZEN JM, FITZGERALD JM, GIBSON P, OHTA K, O'BYRNE P, PEDERSEN SE, PIZZICHINI E, SULLIVAN SD, WENZEL SE, ZAR HJ: Global strategy for asthma management and prevention: GINA executive summary. Eur Respir J 31: 143-178, 2018. https://doi.org/10.1183/13993003.51387-2007

BORLAND C, COX Y, HIGENBOTTAM T: Measurement of exhaled nitric oxide in man. Thorax 48: 1160-1162, 1993. https://doi.org/10.1136/thx.48.11.1160

BRIGHTLING CE, WARD R, WARDLAW AJ, PAVORD ID: Airway inflammation, airway responsiveness and cough before and after inhaled budesonide in patients with eosinophilic bronchitis. Eur Respir J 15: 682-686, 2000. https://doi.org/10.1034/j.1399-3003.2000.15d10.x

CHANG AB, PHELAN PD, ROBERTSON CF, NEWMAN RG, SAWYER SM: Frequency and perception of cough severity. J Paediatr Child Health 37: 142-145, 2001. https://doi.org/10.1046/j.1440-1754.2001.00608.X 
CHANG AB, GLOMB WB: Guidelines for evaluating chronic cough in pediatrics: ACCP evidence-based clinical practice guidelines. Chest 129 (Suppl 1): 260S-283S, 2006. https://doi.org/10.1378/chest.129.1_suppl.260S

CHANG AB: Pediatric cough: children are not miniature adults. Lung 188 (Suppl 1): S33-S40, 2010. https://doi.org/10.1007/s00408-009-9166-2

CHANG AB, OPPENHEIMER JJ, WEINBERGER M, GRANT CC, RUBIN BK, IRWIN RS; CHEST EXPERT COUGH PANEL: Etiologies of chronic cough in pediatric cohorts: CHEST guideline and expert panel report. Chest 152: 607-617, 2017. https://doi.org/10.1016/j.chest.2017.06.006

DE DIEGO A, MARTÍNEZ E, PERPIÑÁ M, NIETO L, COMPTE L, MACIÁN V, SENENT L: Airway inflammation and cough sensitivity in cough-variant asthma. Allergy 60: 1407-1411, 2005. https://doi.org/10.1111/j.13989995.2005.00609.x

FERRARO V, CARRARO S, BOZZETTO S, ZANCONATO S, BARALDI E: Exhaled biomarkers in childhood asthma: old and new approaches. Asthma Res Pract 4: 9, 2018. https://doi.org/10.1186/s40733-018-0045-6

FUJIMURA M, SAKAMOTO S, KAMIO Y, MATSUDA T: Cough receptor sensitivity and bronchial responsiveness in normal and asthmatic subjects. Eur Respir J: 5: 291-295, 1992.

FUJIMURA M, OGAWA H, YASUI M, MATSUDA T: Eosinophilic tracheobronchitis and airway cough hypersensitivity in chronic non-productive cough. Clin Exp Allergy 30: 41-47, 2000. https://doi.org/10.1046/j.13652222.2000.00698.x

HAMID Q, SPRINGALL DR, RIVEROS-MORENO V, CHANEZ P, HOWARTH P, REDINGTON A, BOUSQUET J, GODARD P, HOLGATE S, POLAK JM: Induction of nitric oxide synthase in asthma. Lancet 342: 1510-1513, 1993. https://doi.org/10.1016/S0140-6736(05)80083-2

HESSE AK, DÖRGER M, KUPATT C, KROMBACH F: Proinflammatory role of inducible nitric oxide synthase in acute hyperoxic lung injury. Respir Res 5: 11, 2004. https://doi.org/10.1186/1465-9921-5-11

HOGAN AD, BERNSTEIN JA: GINA updated 2019: Landmark changes recommended for asthma management. Ann Allergy Asthma Immunol 124: 311-313. https://doi:10.1016/j.anai.2019.11.005

HORI A, FUJIMURA M, OHKURA N, TOKUDA A: Involvement of nitric oxide (NO) in cough reflex sensitivity between non-sensitized and OVA-sensitized guinea pigs. Cough 7: 5, 2011. https://doi.org/10.1186/1745-9974-7-5

LIU Q, FUJIMURA M, TACHIBANA S, MYOU S, KASAHARA K, YASUI M: Characterization of increased cough sensitivity after antigen challenge in guinea pigs. Clin Exp Allergy 31: 474-484, 2001. https://doi.org/10.1046/j.1365-2222.2001.00989.x

KHARITONOV SA, YATES D, ROBBINS RA, LOGAN-SINCLAIR R, SHINEBOURNE EA, BARNES PJ: Increased nitric oxide in exhaled air of asthmatic patients. Lancet 343: 133-135, 1994. https://doi.org/10.1016/S0140$\underline{6736(94) 90931-8}$

KILBOURN RG, GROSS SS, JUBRAN A, ADAMS J, GRIFFITH OW, LEVI R, LODATO RF: NG-methyl-L-arginine inhibits tumor necrosis factor-induced hypotension: Implications for the involvement of nitric oxide. Proc Natl Acad Sci U S A 87: 3629-3632, 1990. https://doi.org/10.1073/pnas.87.9.3629

KIM HB, ECKEL SP, KIM JH, GILLILAND FD: Exhaled NO: Determinants and clinical application in children with allergic airway disease. Allergy Asthma Immunol Res 8: 12-21, 2016. https://doi.org/10.4168/aair.2015.8.1.12

KOBZIK L, BREDT DS, LOWENSTEIN CJ, DRAZEN J, GASTON B, SUGARBAKER D, STAMLER JS: Nitric oxide synthase in human and rat lung: immunocytochemical and histochemical localization. Am J Respir Cell Mol Biol 9: 371-377, 1993. https://doi.org/10.1165/ajrcmb/9.4.371

LIPTON SA, CHOI YB, PAN ZH, LEI SZ, CHEN HS, SUCHER NJ, LOSCALZO J, SINGEL DJ, STAMLER JS: A redox-based mechanism for the neuroprotective and neurodestructive effects of nitric oxide and related nitrosocompounds. Nature 364: 626-632, 1993. https://doi.org/10.1038/364626a0

MAECHLER M, ROUSSEEUW P, STRUYF A, HUBERT M, HORNIK K: Cluster: Cluster Analysis Basics and Extensions. R package version 2.0.5., 2016.

MAZZONE SB, CHUNG KF, MCGARVEY L: The heterogeneity of chronic cough: a case for endotypes of cough hypersensitivity. Lancet Respir Med 6: 636-646, 2018. https://doi.org/10.1016/S2213-2600(18)30150-4

MOGENSEN I, JAMES A, MALINOVSCHI A. Systemic and breath biomarkers for asthma: an update. Curr Opin Allergy Clin Immunol 20: 71-79, 2020. https://doi.org/10.1097/ACI.0000000000000599 
MORICE AH, FONTANA GA, BELVISI MG, BIRRING SS, CHUNG KF, DICPINIGAITIS PV, KASTELIK JA, MCGARVEY LP, SMITH JA, TATAR M, WIDDICOMBE J; European Respiratory Society (ERS): ERS guidelines on the assessment of cough. Eur Respir J 29: 1256-1276, 2007. https://doi.org/10.1183/09031936.00101006

MORICE AH, MILLQVIST E, BELVISI MG, BIEKSIENE K, BIRRING SS, CHUNG KF, DAL NEGRO RW, DICPINIGAITIS P, KANTAR A, MCGARVEY LP, PACHECO A, SAKALAUSKAS R, SMITH JA: Expert opinion on the cough hypersensitivity syndrome in respiratory medicine. Eur Respir J 44: 1132-1148, 2014. https://doi.org/10.1183/09031936.00218613

MORICE AH, MILLQVIST E, BIEKSIENE K, BIRRING SS, DICPINIGAITIS P, DOMINGO RIBAS C, HILTON BOON M, KANTAR A, LAI K, MCGARVEY L, RIGAU D, SATIA I, SMITH J, SONG WJ, TONIA T, VAN DEN BERG JWK, VAN MANEN MJG, ZACHARASIEWICZ A: ERS guidelines on the diagnosis and treatment of chronic cough in adults and children. Eur Respir J 55: 1901136, 2020. https://doi.org/10.1183/13993003.01136-2019

NELSON BV, SEARS S, WOODS J, LING CY, HUNT J, CLAPPER LM, GASTON B: Expired nitric oxide as a marker for childhood asthma. J Pediatr 130: 423-427, 1997. https://doi.org/10.1016/S0022-3476(97)70204-X

OHUCHI Y, ICHINOSE M, MIURA M, KAGEYAMA N, TOMAKI M, ENDOH N, MASHITO Y, SUGIURA H, SHIRATO $\mathrm{K}$ : Induction of nitric oxide synthase by lipopolysaccharide inhalation enhances substance P-induced microvascular leakage in guinea-pigs. Eur Respir J 12: 831-836, 1998. https://doi.org/10.1183/09031936.98.12040831

SINGH D, RICHARDS D, KNOWLES RG, SCHWARTZ S, WOODCOCK A, LANGLEY S, O'CONNOR BJ: Selective inducible nitric oxide synthase inhibition has no effect on allergen challenge in asthma. Am J Respir Crit Care Med 176: 988-993, 2007. https://doi.org/10.1164/rccm.200704-5880C

SHIELDS MD, BUSH A, EVERARD ML, MCKENZIE S, PRIMHAK R; BRITISH THORACIC SOCIETY COUGH GUIDELINE GROUP. BTS guidelines: Recommendations for the assessment and management of cough in children. Thorax 63 (Suppl 3): iii1-iii15, 2008. https://doi.org/10.1136/thx.2007.077370

TAYLOR DR, PIJNENBURG MW, SMITH AD, DE JONGSTE JC. Exhaled nitric oxide measurements: clinical application and interpretation. Thorax 61: 817-827, 2006. https://doi.org/10.1136/thx.2005.056093

TURNER S. Exhaled nitric oxide and the management of childhood asthma - yet another promising biomarker "has been" or a misunderstood gem. Paediatr Respir Rev 16: 88-96, 2015. https://doi.org/10.1016/j.prrv.2014.07.005

VARECHOVA S, PLEVKOVA J, HANACEK J, TATAR M: Role of gender and pubertal stage on cough sensitivity in childhood and adolescence. J Physiol Pharmacol 59: 719-726, 2008. 